\title{
Front Matter: Volume 10199
}

, "Front Matter: Volume 10199," Proc. SPIE 10199, Geospatial Informatics, Fusion, and Motion Video Analytics VII, 1019901 (30 May 2017); doi: $10.1117 / 12.2270666$

SPIE. Event: SPIE Defense + Security, 2017, Anaheim, CA, United States 


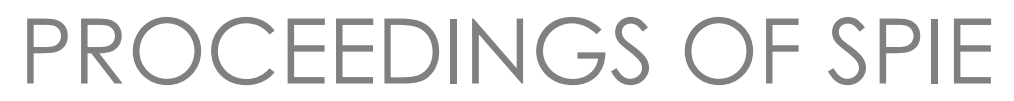

\title{
Geospatial Informatics, Fusion, and Motion Video Analytics VII
}

\author{
Kannappan Palaniappan \\ Peter J. Doucette \\ Gunasekaran Seetharaman \\ Anthony Stefanidis
}

Editors

12 April 2017

Anaheim, California, United States

Sponsored and Published by

SPIE 
The papers in this volume were part of the technical conference cited on the cover and title page. Papers were selected and subject to review by the editors and conference program committee. Some conference presentations may not be available for publication. Additional papers and presentation recordings may be available online in the SPIE Digital Library at SPIEDigitallibrary.org.

The papers reflect the work and thoughts of the authors and are published herein as submitted. The publisher is not responsible for the validity of the information or for any outcomes resulting from reliance thereon.

Please use the following format to cite material from these proceedings:

Author(s), "Title of Paper," in Geospatial Informatics, Fusion, and Motion Video Analytics VII, edited by Kannappan Palaniappan, Peter J. Doucette, Gunasekaran Seetharaman, Anthony Stefanidis, Proceedings of SPIE Vol. 10199 (SPIE, Bellingham, WA, 2017) Seven-digit Article CID Number.

ISSN: 0277-786X

ISSN: 1996-756X (electronic)

ISBN: 9781510608993

ISBN: 9781510609006 (electronic)

Published by

SPIE

P.O. Box 10, Bellingham, Washington 98227-0010 USA

Telephone +1 3606763290 (Pacific Time) · Fax +1 3606471445

SPIE.org

Copyright (c) 2017, Society of Photo-Optical Instrumentation Engineers.

Copying of material in this book for internal or personal use, or for the internal or personal use of specific clients, beyond the fair use provisions granted by the U.S. Copyright Law is authorized by SPIE subject to payment of copying fees. The Transactional Reporting Service base fee for this volume is $\$ 18.00$ per article (or portion thereof), which should be paid directly to the Copyright Clearance Center (CCC), 222 Rosewood Drive, Danvers, MA 01923. Payment may also be made electronically through CCC Online at copyright.com. Other copying for republication, resale, advertising or promotion, or any form of systematic or multiple reproduction of any material in this book is prohibited except with permission in writing from the publisher. The CCC fee code is $0277-786 \mathrm{X} / 17 / \$ 18.00$.

Printed in the United States of America.

Publication of record for individual papers is online in the SPIE Digital Library.

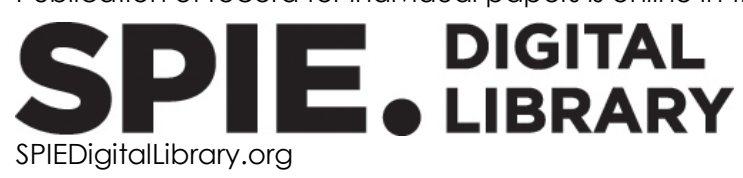

Paper Numbering: Proceedings of SPIE follow an e-First publication model. A unique citation identifier (CID) number is assigned to each article at the time of publication. Utilization of CIDs allows articles to be fully citable as soon as they are published online, and connects the same identifier to all online and print versions of the publication. SPIE uses a seven-digit CID article numbering system structured as follows:

- The first five digits correspond to the SPIE volume number.

- The last two digits indicate publication order within the volume using a Base 36 numbering system employing both numerals and letters. These two-number sets start with 00, 01, 02, 03, 04, 05, 06, 07, 08, 09, OA, OB ... OZ, followed by 10-1Z, 20-2Z, etc. The CID Number appears on each page of the manuscript. 


\title{
Contents
}

\author{
$\checkmark$ Authors \\ vii Conference Committee
}

\section{SESSION 1 VIDEO ANALYSIS}

1019903 Pilot study on real-time motion detection in UAS video data by human observer and image exploitation algorithm [10199-3]

1019904 Data transpositioning with content-based image retrieval [10199-4]

1019905 An analysis of optical flow on real and simulated data with degradations [10199-5]

1019906 Geopositioning with a quadcopter: Extracted feature locations and predicted accuracy without a priori sensor attitude information [10199-6]

\section{SESSION 2 PHOTOGRAMMETRY AND UNCERTAINTY PROPAGATION}

1019907 Using image quality metrics to identify adversarial imagery for deep learning networks [10199-7]

1019908 Methods for the specification and validation of geolocation accuracy and predicted accuracy [10199-8]

1019909 Three-dimensional scene reconstruction from a two-dimensional image [10199-9]

10199 OA Correlation-agnostic fusion for improved uncertainty estimation in multi-view geo-location from UAVs [10199-10]

\section{SESSION 3 GEOSPATIAL ANALYSIS}

$101990 \mathrm{C}$ Geoparsing text for characterizing urban operational environments through machine learning techniques [10199-12]

10199 OD A machine learning pipeline for automated registration and classification of 3D lidar data [10199-13]

$10199 \mathrm{OH}$ Standardized acquisition, storing and provision of 3D enabled spatial data [10199-17]

10199 Ol Concept for a common operational picture in a guidance vehicle [10199-18] 
Proc. of SPIE Vol. $101991019901-4$ Downloaded From: https://www.spiedigitallibrary.org/conference-proceedings-of-spie on 26 Apr 2023
Terms of Use: https://www.spiedigitallibrary.org/terms-of-use 


\title{
Authors
}

Numbers in the index correspond to the last two digits of the seven-digit citation identifier (CID) article numbering system used in Proceedings of SPIE. The first five digits reflect the volume number. Base 36 numbering is employed for the last two digits and indicates the order of articles within the volume. Numbers start with 00, 01, 02, 03, 04, 05, 06, 07, 08, 09, 0A, 0B...0Z, followed by 10-1Z, 20-2Z, etc.

\author{
Barngrover, Chris, 05 \\ Beyerer, Jürgen, 03 \\ Braun, Aaron, 06 \\ Brown, Andrew P., OA \\ Brüstle, Stefan, 03 \\ Calfas, George W., 08 \\ Carr, Jacqueline, 09 \\ Chandrasekaran, Shivkumar, OA \\ Chellappan, Karthik, OA \\ Dolloff, John, 06, 09 \\ Eck, Ralf, ol \\ Edwards, David, 06 \\ Garfinkle, Noah W., 08 \\ Harguess, Josh, 05, 07 \\ Heinze, Norbert, 03 \\ Hild, Jutta, 03 \\ Hottel, Bryant, 06 \\ Hou, Daqing, 04 \\ Jacobs, Eddie, OB \\ Krüger, Wolfgang, 03 \\ Maier, Sebastian, $\mathrm{OH}$, $\mathrm{Ol}$ \\ Manno, Michael J., 04 \\ Miclat, Jeremy, 07 \\ Parkins, Franz, OB \\ Peinsipp-Byma, Elisabeth, $03, \mathrm{OH}$ \\ Perkins, Timothy K., 08 \\ Raheema, Julian, 07 \\ Rahimi, Amin, 05 \\ Rajagopal, Abhejit, OA \\ Selig, Lucas, 08 \\ Sundlie, Paul O., OD \\ Taylor, Clark N., OD \\ Theiss, Henry, 06 \\ Trantelle, Patrick, 03 \\ Unmüßig, Gabriel, 03 \\ Voit, Michael, 03 \\ Wagner, Boris, $\mathrm{OH}, \mathrm{Ol}$
}


Proc. of SPIE Vol. $101991019901-6$

Downloaded From: https://www.spiedigitallibrary.org/conference-proceedings-of-spie on 26 Apr 2023 Terms of Use: https://www.spiedigitallibrary.org/terms-of-use 


\section{Conference Committee}

Symposium Chair

Donald A. Reago Jr., U.S. Army Night Vision \& Electronic Sensors

Directorate (United States)

Symposium Co-chair

Arthur A. Morrish Raytheon Space and Airborne Systems

(United States)

Conference Chairs

Kannappan Palaniappan, University of Missouri-Columbia (United States)

Peter J. Doucette, U.S. Geological Survey (United States)

Gunasekaran Seetharaman, U.S. Naval Research Laboratory (United States)

Anthony Stefanidis, George Mason University (United States)

Conference Program Committee

Alex Aved, Air Force Research Laboratory (United States) John A. Berger, Toyon Research Corporation (United States)

Erik P. Blasch, Air Force Research Laboratory (United States)

Subhasis Chaudhuri, Indian Institute of Technology Bombay (India)

Ananda Shankar Chowdhury, Jadavpur University (India)

Shiloh L. Dockstader, Harris Corporation (United States)

Joshua D. Harguess, SPAWAR Systems Center Pacific (United States)

Jutta E. Hild, Fraunhofer-Institut für Optronik, Systemtechnik und

Bildauswertung (Germany)

Stefan R. Jaeger, National Library of Medicine (United States)

Simon J. Julier, University College London (United Kingdom)

Chandra Kambhamettu, University of Delaware (United States)

Ross Maciejewski, Arizona State University (United States)

Richard J. Maude, University of Oxford (United Kingdom)

Upesh Patel, U.S. Army Communications-Electronics Command (United States)

Matthew F. Pellechia, Harris Corporation (United States)

V. B. Surya Prasath, University of Missouri-Columbia (United States)

Sartaj Sahni, University of Florida (United States)

Carl Salvaggio, Rochester Institute of Technology (United States)

Stefano Soatto, University of California, Los Angeles (United States) 
William R. Thissell, Chenega Technical Innovations, LLC

(United States)

Jonathan D. Tucker, Lockheed Martin Corporation (United States)

Zhuoting Wu, U.S. Geological Survey (United States)

Alina Zare, University of Florida (United States) 